\title{
Micronutrient intakes and inadequacies in school-going Irish adolescents
}

\author{
M. P. O'Connor ${ }^{1}$, N. M. O’Brien ${ }^{1}$, K. O’Sullivan ${ }^{2}$ and T. P. O'Connor ${ }^{1}$ \\ ${ }^{1}$ Department of Food and Nutritional Sciences and ${ }^{2}$ Department of Statistics, University College Cork, Republic of Ireland
}

The period of adolescence is one of rapid growth and development, and optimal dietary intake during the teenage years is vital. The demand for energy and most nutrients is high, and adolescents gain approximately $15 \%$ of their final adult height and about $45 \%$ of the maximal skeletal mass ${ }^{(1)}$. Adolescents' intakes of fat and added sugars exceed guideline amounts in many countries, while intakes of micronutrients, most notably $\mathrm{Fe}$ and $\mathrm{Ca}$, do not meet the recommendations, particularly in girls ${ }^{(2)}$. Boys' and girls' nutrient requirements differ, with boys needing more energy and protein and girls' Fe requirements being higher because of menstruation. The National Diet and Nutrition Survey reported in 2003 that $44 \%$ of adolescent girls aged 11-18 years had low Fe intakes (below the lower reference nutrient intake (RNI) for $\mathrm{Fe})^{(3)}$. A longitudinal study over three school years of changes in dietary intake was carried out annually from 2005 to 2007 inclusive in three secondary schools in County Cork, Republic of Ireland. A $3 \mathrm{~d}$ weighed dietary record was used to collect food intake from 158 students aged 12-17 years in 2005 (ninety-seven females, sixty-one males). Analysis of dietary intake data was determined using WISP ${ }^{\odot}$ (Tinuviel Software, Llanfechell, Anglesey, UK), which is based on McCance and Widdowson's The Composition of Foods Sixth Edition ${ }^{(4)}$. Mean daily intakes of five essential micronutrients are reported (Table). Mean daily Ca (mg) and folate ( $\mu \mathrm{g}$ ) intakes were significantly higher in males $(P<0.05)$. The males in this group also had significantly higher intakes of Fe and riboflavin compared with the females $(P<0.001)$.

\begin{tabular}{|c|c|c|c|c|c|c|}
\hline \multirow[b]{2}{*}{ Micronutrient } & \multicolumn{2}{|c|}{ Total group ( $n$ 158) } & \multicolumn{2}{|c|}{ Males $(n$ 61) } & \multicolumn{2}{|c|}{ Females $(n$ 97) } \\
\hline & Mean & SD & Mean & $\mathrm{SD}$ & Mean & SD \\
\hline$\overline{\mathrm{Ca}(\mathrm{mg})}$ & 899 & 480 & $1078 *$ & 629 & 786 & 311 \\
\hline $\mathrm{Fe}(\mathrm{mg})$ & 11.0 & 5.0 & $13.0 * *$ & 5.9 & 9.7 & 3.7 \\
\hline Folate $(\mu \mathrm{g})$ & 235 & 128 & $287^{*}$ & 169 & 203 & 77 \\
\hline Riboflavin(mg) & 1.8 & 1.1 & $2.3 * *$ & 1.4 & 1.5 & 0.7 \\
\hline Vitamin C (mg) & 81.4 & 54.2 & 82.5 & 60 & 80.7 & 50.6 \\
\hline
\end{tabular}

Values were significantly different between genders: $* P<0.05, * * P<0.001$

A substantially high percentage of females $(91 \%)$ had Fe intakes that did not meet the UK RNI ${ }^{(5)}$ compared with males $(46 \%)$. Over half females (57\%) and males (54\%) in this cohort had Ca intakes below the UK RNI for Ca. In contrast only $20 \%$ of males and $22 \%$ of females had vitamin $\mathrm{C}$ intakes below the UK RNI. Males had relatively good intakes of $\mathrm{Ca}$, Fe, folate, riboflavin and vitamin C. Average daily intakes of $\mathrm{Ca}$ and $\mathrm{Fe}$ for females were $(786 \mathrm{mg})$ and $(9.7 \mathrm{mg})$ respectively. These findings suggest that $\mathrm{Ca}$ and $\mathrm{Fe}$ intakes in Irish adolescent girls are below the recommended amounts. Continuously low intakes of these nutrients, particularly Fe, may led to suboptimal Fe status and anaemia in Irish teenage girls.

This material is based on works supported by safefood, the Food Safety Promotion Board, under grant no. 04-PG-20.

1. Spear B (2002) J Am Diet Assoc 102, Suppl. 3, S23-S29.

2. Rolland-Cachera MF, Belliste F \& Deheeger M (2000) Eur J Clin Nutr 54, Suppl. 1, S41-S46.

3. Thane CW, Bates CJ \& Prentice A (2003) Pub Health Nutr 6, 485-496.

4. Food Standards Agency (2002) McCance \& Widdowson's The Composition of Foods Sixth Edition. Cambridge: Royal Society of Chemistry.

5. Department of Health (1991) Dietary Reference Values for Food Energy and Nutrients for the United Kingdom. Report on Health and Social Subjects no. 41. London: H. M. Stationery Office. 